\title{
The Effects of Skills-Based Health Education on Students' Knowledge, Attitude, and Behavior towards the Prevention of Environment-Based Diseases
}

\author{
$1^{\text {st }}$ Yuni Wijayanti \\ dept. Public Health, Faculty of \\ Sport Science \\ Universitas Negeri Semarang \\ Semarang, Indonesia \\ yuniwija@mail.unnes.ac.id
}

\author{
$2^{\text {nd }}$ Anik Setyo Wahyuningsih \\ dept. Public Health, Faculty of \\ Sport Science \\ Universitas Negeri Semarang \\ Semarang, Indonesia
}

1

\begin{abstract}
Environmental-based diseases are ones of the causes of death. This research aims to analyze the influence of Skills-Based Health Education (SBHE) on knowledge, attitude, and behavior of the elementary school students of Sekaran Semarang towards the prevention of environmental diseases. The study used a quasi-experimental design with a one-group pretestposttest design. A bivariate analysis of 68 students' responses using McNemar test showed a significant effect of SBHE on students' knowledge and attitude but no effect on their behavior.
\end{abstract}

Keywords- SBHE, environment, knowledge, attitude, behavior.

\section{INTRODUCTION}

Environmental-based diseases still dominate health problems in developing countries. Environmental-based diseases can occur due to an interactive relationship between human, behavioral, and environmental components that have potential diseases [1]. Environmental-based diseases are causes of serious public health and even the leading causes of death. Public awareness of the importance of maintaining hygiene and health is still low resulting in various diseases easily emerge and develop. One of the environmental-based diseases is dengue fever. HL Blum's states that environmental health and human behavior are two dominant factors that affect the health status of a society [2].

Various human development activities that done individually, in groups or programmed because the interests of the state or even the world will have impacts. These factors can cause susceptibility to the body's ability to ward off diseases so that these generate various environmental-based diseases that complement the collection of diseases in Indonesia [3].

At present, environment-based diseases are still public health problems in Indonesia. Upper respiratory tract infection and diarrhea which is an environment-based disease always included in the top 10 diseases in almost Puskesmas throughout Indonesia. The high prevalence of environmental-based diseases, among others, is caused by environmental factors and low clean and healthy life behavior4. Purwandari et al. stated that there is a significant relationship between handwashing behavior and diarrhea incidence in school-aged children in Jember District (p-value: 0,000)5. According to a research by
Rusmanto and Mukono, it was said that there is a significant relationship between personal hygiene with the helminth infection (p-value: 0,045) [6]. The results showed that there were differences of knowledge (p-value: 0.001) and hand washing behavior (p-value: 0,039) among the experimental group and control group [7].

The results of preliminary observations made on February 9, 2018, showed that the environmental health conditions in SDN 01 and SDN 02 Sekaran Semarang were classified as lacking. This was indicated by the lack of sanitation around the school that is still dirty, smelly toilets, stagnant waterways, improper waste management, and school canteens look dirty and unhygienic.

The results of interviews with the Principal of SDN 01 and SDN 02 Sekaran Semarang revealed that there are ten diseases often occur in their students, namely: fever (influenza), upper respiratory tract infection, sore throat, diarrhea, typhoid, chicken pox, dengue hemorrhagic fever, conjunctivitis (red eye), and skin diseases. So far, students and teachers have not received any material on basic skills in the form of health education (SBHE), or educational health in order to prevent the occurrence of environmental-based diseases. According to both principals, that students' knowledge, attitudes and behaviors about environmental health in schools are lacking.

Based on the above background information, the problem under study can be stated as 'How does SBHE influence the knowledge, attitude, and behavior of students as an environmental-based disease prevention on SDN 01 and SDN 02 Sekaran Semarang?'. The purpose of this study is to determine the effect of SBHE on students' knowledge, attitude, and behavior towards the prevention of environment-based diseases.

\section{MATERIAL AND METHOD}

This study used a quasi-experimental design with one group pre-test and post-test design. The study was conducted in 3 months. The time of research implementation was in March until May 2018. The study population was elementary 
school students of SDN 01 and SD N 02 Sekaran Semarang amounting to 408 students. The sample size was 68 students generated using a purposive sampling technique.

The research instruments used in this research are observation sheets, questionnaires for knowledge, attitude, and behavior. The observation sheets were used to record and assess SBHE and environmental health conditions at SDN 01 and SDN 02 Sekaran Semarang. Questionnaires are used to determine or measure the level of knowledge, attitudes, and behavior of students about SBHE. The data were collected by means of measurements and interviews. These techniques are used to retrieve data about the level of knowledge, attitudes, and behavior of students before and after implementing SBHE as a preventive effort against the incidence of environmentalbased diseases.

A univariate analysis was performed by using frequency distribution test on a computer application. Univariate analysis results presented in the form of narration, tables, and graphs, which consists of knowledge, attitude, and behavior of students SDN 01 and SDN 02 Sekaran Semarang. A bivariate analysis in this study was conducted to analyze the effect of SBHE on the level of knowledge, attitude, and behavior of students at SDN 01 and SDN 02 Sekaran Semarang. The statistical test used was the McNemar test.

\section{RESULT AND DISCUSSION}

The result of univariate analysis of the knowledge variable showed that the pretest score of the students' knowledge of the "Bad" category is still $44.1 \%$. There was an increase in the value of knowledge of "Good" category, from $55.9 \%$ to $72.1 \%$. There was a decrease in the value of knowledge category "Bad" from $44.1 \%$ to $27.9 \%$. The students' knowledge data can be seen in Table 1.

TABLE I. KNOWLEDGE TEST BEFORE AND AFTER SBHE

\begin{tabular}{|c|c|c|c|c|}
\hline \multirow{2}{*}{$\begin{array}{c}\text { Know- } \\
\text { ledge }\end{array}$} & \multicolumn{4}{|c|}{ Test results } \\
\cline { 2 - 5 } & Pre & \% & Post & \% \\
\hline Bad & 38 & 44,1 & 19 & 27,9 \\
\hline Good & 30 & 55,9 & 49 & 72,1 \\
\hline Total & 68 & 100 & 68 & 100 \\
\hline
\end{tabular}

The results of univariate analysis of attitude variable showed that the pretest attitude of students attitude of "Bad" category is still high, that is $80.9 \%$. But there was an increase in attitude value category "Good", ie from $19.1 \%$ to $54.4 \%$ while the attitude value category "Bad" decreased from $80.9 \%$ to $45.6 \%$. Students' attitude data on SBHE can be seen in Table 2 .

TABLE II. AATTITUDE TEST BEFORE AND AFTER SBHE

\begin{tabular}{|c|c|c|c|c|}
\hline \multirow{2}{*}{$\begin{array}{c}\text { Atti- } \\
\text { tude }\end{array}$} & \multicolumn{4}{|c|}{ Test results } \\
\cline { 2 - 5 } & Pret & \% & Post & \% \\
\hline Bad & 55 & 80,9 & 31 & 45,6 \\
\hline Good & 13 & 19,1 & 37 & 54,4 \\
\hline Total & 68 & 100 & 68 & 100 \\
\hline
\end{tabular}

The results of pre-test and post-test (Bad or Good category) on student behavior variable did not show any decrease or increase. The data about the result of students' behavior can be seen in Table 3 .

TABLE III. BBEHAVIOR TEST BEFORE AND AFTER SBHE

\begin{tabular}{|c|c|c|c|c|}
\hline \multirow{2}{*}{ Beha-vior } & \multicolumn{4}{|c|}{ Test results } \\
\cline { 2 - 5 } & Pret & \% & Post & \% \\
\hline Bad & 14 & 20,6 & 14 & 20,6 \\
\hline Good & 54 & 79,4 & 54 & 79,4 \\
\hline Total & 68 & 100 & 68 & 100 \\
\hline
\end{tabular}

The bivariate analysis using McNemar test in this study showed a significant effect of SBHE on the knowledge and attitude of the students of SDN Sekaran Semarang. However, the behavior of elementary school students SDN Sekaran Semarang was not influenced significantly by the provision of SBHE. The p-value values of the three bivariate analyzes can be seen in Table 4.

TABLE IV. BIVARIATE ANALYSIS RESULTS

\begin{tabular}{|c|c|}
\hline Varilable & p-value \\
\hline Knowledge & 0,000 \\
\hline Attitude & 0,000 \\
\hline Behavior & 1,000 \\
\hline
\end{tabular}

Providing SBHE to elementary school students of SDN Sekaran Semarang shows an improvement of students' knowledge about the basic skill of health equals to $63.33 \%$. This student knowledge is the main provision in the framework of disease prevention, especially environmentalbased disease [8]. Elementary students who have good knowledge of SBHE can reduce the risk of contracting the disease in school. In this way the incidence of environmentbased diseases in elementary school students can be suppressed $^{9}$. The result of data analysis showed that there is a significant SBHE influence to students' knowledge.

The attitude of elementary school students SDN Sekaran Semarang changes after the provision of SBHE. The results of the study show a very high increase in students' attitudes ("Good" category) equals to $185 \%$. The attitude of elementary students who have been formed like this is based on the good students' knowledge as well. The result of the research data analysis shows the significant effect of SBHE on the attitude of the students of SDN Sekaran Semarang. This is in accordance with the results of the study of Elsa et al (2014) which explains that the application of education of environmental care characters using inquiry methods can improve understanding and lead to changes in the attitude of the pupil [10].

SBHE that has been given once cannot result in any change of students' behavior. It is said by Fountain and Gillespie that achieving knowledge, attitude and skill objectives takes time, and is unlikely to be the result of a single lesson [11]. In this study, the behavioral variable is not significantly affected by SBHE on students. This is in line with the results of Muliana et al.'s study which states that the average grade of students' knowledge of environment is in the 
high category while the students' behavior is in the low category [12].

\section{CONCLUSION}

Based on the results of research that has been done can be concluded that the provision of SBHE improves the level of knowledge and attitude variables of the SDN Sekaran Semarang students. The behavior variable, however, shows the same value between before and after SBHE to the students. Besides, SBHE influences significantly to the level of knowledge and attitude variables but not to the behavioral variable as this newly-performed training has not been able to change student behavior.

The results of this research are expected to provide information on the basic educational environment related to the prevention of environment-based diseases through the application of SBHE to students. It is expected that other researchers will conduct related studies by increasing the number of treatments (training) and using other research designs.

\section{REFERENCES}

[1] Achmadi, Manajemen Penyakit Berbasis Wilayah. (Universitas Indonesia Press, 2008).

[2] Hudyastuti. Penyakit Menular Berbasis Lingkungan Penyebab Utama Kematian. (http://berita.kapanlagi.com/pernik/penyakit-berbasislingkungan-penyebab-utama-kematian-58xxdw1.html, 2007)

[3] Hasyim. "Manajemen Penyakit Lingkungan Berbasis Wilayah," Jurnal Manajemen Pelayanan Kesehatan, vol. 11(2), pp. 72 - 762008.
[4] Arifin, Penyakit Berbasis Lingkungan. (http://environmentalsanitation.wordpress.com/category/penyakitberbasis-lingkungan/, 2009).

[5] Purwandari, Ardiana, and Wantiyah, Hubungan antara Perilaku Mencuci tangan dengan Insiden Diare pada Anak Usia Sekolah di Kabupaten Jember. Jurnal Keperawatan, ISSN: 2086-3071 (2013).

[6] Rusmanto and Mukono. "Hubungan antara Personal higiene Siswa sekolah Dasar dengan kejadian Penyakit Kecacingan." The Indonesia Journal of Public Health, vol. 8(3), 2012.

[7] Susilaningsih and Hadiatama, Pengaruh Pendidikan Kesehatan terhadap Perilaku Mencuci Tangan Siswa Sekolah Dasar. Proseding Konferensi Nasional PPNI Jawa Tengah (2013).

[8] Anies, Mewaspadai Penyakit Lingkungan. Berbagai Gangguan Kesehatan Akibat Pengaruh Faktor Lingkungan. (Jakarta, PT Gramedia, 2005).

[9] WHO. 2003. The Physical School Environment: An Essential Component of a Health-Promoting School. WHO Information Series on School Health (Document 2, Geneva, http://www.who.int/school youth health/media/en/physical sch enviro nment_v2.pdf, 2003).

[10] Elsa, Khairil, and Yunus. "Penerapan Pendidikkan Karakter Peduli Lingkungan melalui Metode Inkuiri terhadap Sikap dan Perilaku Siswa pada materi Pencemaran dan Kerusakan Lingkungan di SMP N 6 Banda Aceh," Jurnal Biotik, vol. 2(1), pp. 1-76, 2014.

[11] Fountain and Gillespie, Assessment Strategies for Skills-based Health Education. Prepared for UNICEF Education Section, (New York. http://citeseerx.ist.psu.edu/viewdoc/download?doi=10.1.1.544.5778\&rep =rep1\&type=pdf, 2003).

[12] Muliana, Hamama, and Zamzam. "Hubungan Pengetahuan Lingkungan terhadap Sikap Siswa pada Pengelolaan Kebersihan Sekolah," Jurnal Dedikasi Pendidikkan, vol. 2(1), pp. 8-13, 2018. 